\title{
SOWING THE SEEDS OF FIRE AND OAK IN THE EASTERN US: A TRIBUTE TO BUELL ET AL. 1954
}

\author{
Marc D. Abrams \\ Department of Ecosystem Science and Management, Pennsylvania State University \\ 307 Forest Resources Building, University Park, Pennsylvania 16802, USA \\ Tel.: +001-814-865-4901; e-mail: ag1@psu.edu
}

RESUMEN

\begin{abstract}
A 323-year-old white oak (Quercus alba L.) tree in Mettler's Woods in central New Jersey, USA, was the subject of the Buell et al. 1954 paper. They identified six fire scars formed between 1641 and 1711, with a mean fire return interval of 8.6 years over this period. The fires were primarily associated with narrow rings, which are indicative of drought years. The cessation of fire scars occurred shortly after European settlement. The results of this groundbreaking study provided the first estimate of pre-European settlement fire history for mid-Atlantic oak forests and evidence that these fires were a function of Native American burning combined with drought years. The authors proposed that oak and hickory establishment (forming distinct age cohorts) was associated with recurring fire, that European settlement corresponded to reduced burning in some Eastern forests, that the cessation of burning might impact oak-hickory forest dynamics, and that old-growth forests should be preserved and studied for ecological purposes.
\end{abstract}

Un roble blanco (Quercus alba L.) de 323 años de edad ubicado en los bosques Mettler en el centro de Nueva Jersey, fue objeto del trabajo de Buell et al., publicado en 1954. Los autores identificaron seis cicatrices de fuego formadas entre 1641 y 1711 , con un intervalo medio de retorno del fuego de 8,6 años en ese período. Los fuegos fueron asociados primariamente con anillos de crecimiento estrechos, lo que es indicativo de años secos. El cese de cicatrices ocurrió inmediatamente después de la colonización europea. Los resultados de este innovador estudio proveyeron la primera estimación de la historia de fuego del período pre-colonización Europea para los bosques de roble blanco del Atlántico, y evidencian que esos fuegos ocurrieron en función de las quemas realizadas por Americanos Nativos y de los años secos. Los autores propusieron que el establecimiento de robles y nogales (formando diferentes cohortes) estuvo asociada con fuegos recurrentes, que la colonización Europea se corresponde con una reducción de fuegos en bosques del Este de los EEUU, que el cese de eventos de fuego podría impactar en la dinámica de los bosques de roble y nogal, y que los bosques antiguos deben preservarse y estudiarse con propósitos ecológicos.

Keywords: fire history, Mettler's Woods, Murray Buell, New Jersey, Quercus alba

Citation: Abrams, M.D. 2016. Sowing the seeds of fire and oak in the eastern US: a tribute to Buell et al. 1954. Fire Ecology 12(2): 7-12. doi: 10.4996/fireecology.1202007 


\section{INTRODUCTION}

I knew Professor Murray Fife Buell by reputation only. He started his professional career in 1935 and retired in 1971. Following his death in 1975, a very moving obituary was written by Bormann and Pearson (1975), which makes me sorry that I never met the man. Nevertheless, Dr. Buell had a very big influence on my career. He was born in New Haven, Connecticut, USA, and earned a B.S. at Cornell University in 1930. Dr. Buell then earned his M.A. and Ph.D. at the University of Minnesota in 1934 and 1935, respectively. He studied with W.S. Cooper, who stimulated his interest in plant ecology. He worked on the faculty of North Carolina State University and conducted research on the paleoecology of bogs, plant succession, and tension zones between vegetation types. In 1947, he moved to Rutgers University where he became Professor of Botany and Director of the William L. Hutcheson Forest. He and his students studied ecology in relation to land-use management and human impacts on vegetation. Between 1937 and 1959, he spent many of his summers teaching at the University of Minnesota's Lake Itasca Biological Station, where he trained and inspired many ecologists of our generation. In 1962, Dr. Buell served as President of the Ecological Society of America (ESA) and was given the Eminent Ecologist Award by the Society in 1970. The Murray F. Buell Award was established by ESA in 1977. Dr. Buell died July 3, 1975, while on a field trip to the New Jersey Pine Barrens.

The Buell et al. 1954 paper includes his wife Dr. Helen Buell and Rutgers colleague Dr. John Small as co-authors. It was published in Torreya, once a separate journal of the Torrey Botanical Society, for which the Journal of the Torrey Botanical Society is better known. Papers published in Torreya are generally more modest in scope and scientific rigor that focus on species distribution, floristics, conservation, and environmental concerns, including field trip reports. The 1954 paper is short but certainly not modest in scope or impact. When I first read it as a twenty-something postdoctoral researcher at Kansas State University, it was a revelation. It was one of the earliest papers I found that actually dated individual fire scars on oak trees and proposed that fires set by Native Americans were an integral part of the ecology of Eastern oak forests. It is a great example of big things sometimes coming in small packages.

The subject of this paper is a single large white oak (Quercus alba L.) tree at Mettler's Woods in central New Jersey that blew down in a severe windstorm in November 1950. The researchers brought a basal cross section of the tree back to the lab to study and date its tree rings and fire scars, including noting the presence of charcoal in the scars. They estimated that the tree started life in 1627 and was scarred by fire six times between 1641 and 1711. This computes to a mean fire return interval of about 8.6 years over this 70 -year period. They also investigated the relationship of tree ring width and fire years and concluded that fires were primarily associated with narrow rings, which are indicative of drought years.

Buell et al. were intrigued by the fact that the last fire in this 323-year-old tree was recorded in 1711, so they looked into the historical records of human settlement. They were likely spurred by Day's (1953) contemporaneous paper on the importance of Indian fires in New England, which they cited. Prior to European settlement in 1701, central New Jersey had a long and active history of Native Americans occupation. According to Day (1953), Indians were responsible for setting prescribed and accidental fires that were recorded by European explorers as early as 1610 and up until the time they left the region about 100 years later. Buell's data showed that the cessation of fire scars on the study tree corresponded with the timing of European settlement. Furthermore, they surmised that the oak and hickory 
trees that existed in the forest in the middle twentieth century dated back to a time of frequent fires set by Native Americans. Thus, this is one of earliest papers to suggest a relationship between oak and hickory establishment and fire. The Buell paper concludes with some questions and conjecture about the future composition of the forest and whether Bard's (1952) opinion, that the oak-hickory forest at Mettler's Woods represents a climax community, is valid. Rather than agreeing or disagreeing with the climax status of Eastern oak, they instead argued for preservation of the forest to study its future composition.

During my career, I continue to be amazed at the breadth and depth of this early paper that lacks the scientific rigor now expected in our research endeavors. Frankly, this paper would not get published today in a refereed scientific journal. Imagine trying to publish a dendrochronology or fire history paper based on one tree in one forest, and with hand-measured tree rings without crossdating. Yet, sometimes a single tree and rather crude measurements can tell the whole story if it is being studied by the right people who can put all the pieces of the puzzle together. In this case, the authors were able to estimate the pre-European settlement fire history that is within the accepted range for mid-Atlantic oak forests (Shumway et al. 2001, Guyette et al. 2012). They suggested that these fires were a function of Native American burning combined with drought years, that oak and hickory recruitment was linked to recurring fire, that European settlement corresponded to reduced burning in some Eastern forests, that the resulting low or no fire regime might impact future tree species establishment, and that old-growth oak forests should be preserved and studied for ecological purposes. My earliest study of fire history in oak gallery forests in eastern Kansas (Abrams 1985) and synthesis of fire and oak for the eastern US (Abrams 1992) were inspired, at least in part, by reading the classic Buell et al. 1954 paper.

\section{ACKNOWLEDGEMENTS}

I wish to thank Dr. G. Nowacki for his review of this paper.

\section{LITERATURE CITED}

Abrams, M.D. 1985. Fire history of oak gallery forests in a northeast Kansas tallgrass prairie. American Midland Naturalist 114: 188-191. doi: 10.2307/2425255

Abrams, M.D. 1992. Fire and the development of oak forests. Bioscience 42: 346-353. doi: $10.2307 / 1311781$

Bard, G.E. 1952. Secondary succession on the Piedmont of New Jersey. Ecological Monographs 22: 195-215. doi: 10.2307/1943565

Bormann, H.F., and P.G. Pearson. 1975. Murray Fife Buell 1906-1975. Bulletin of the Ecological Society of America 56: 26.

Buell, M.F., H.F. Buell, and J.A. Small. 1954. Fire in the history of Mettler's Woods. Bulletin of the Torrey Botanical Club 81: 253-255. doi: 10.2307/2481817

Day, G.M. 1953. The Indian as an ecological factor in the northeastern forest. Ecology 34: 329346. doi: $10.2307 / 1930900$

Guyette, R.P., M.C. Stambaugh, D.C. Dey, and R. Muzika. 2012. Predicting fire frequency with chemistry and climate. Ecosystems 15: 322-335. doi: 10.1007/s10021-011-9512-0

Shumway, D.L., M.D. Abrams, and C.M. Ruffner. 2001. A 400-year history of fire in an oldgrowth oak forest in western Maryland, USA. Canadian Journal of Forest Research 31: 1437-1443. doi: 10.1139/x01-079 